\title{
Conceptual Comparison of Internal Audit and Internal Control in the Marketing Environment
}

\author{
Václav Kupec ${ }^{1, * \mathbb{D}}$, Přemysl Písař ${ }^{1}$, Michal Lukáč ${ }^{2}$ and Gabriela Pajtinková Bartáková ${ }^{3}$ \\ 1 Faculty of Economic Studies, University of Finance and Administration, 10100 Prague, Czech Republic; \\ premyslpisar@mail.vsfs.cz \\ 2 Faculty of Social Sciences, University of Ss. Cyril and Methodius in Trnava, 91701 Trnava, Slovakia; \\ michal.lukac@ucm.sk \\ 3 Faculty of Management, Comenius University in Bratislava, 82005 Bratislava, Slovakia; \\ gabriela.bartakova@fm.uniba.sk \\ * Correspondence: vkupec@mail.vsfs.cz; Tel.: +420-210-088-800
}

Citation: Kupec, V.; Písař, P.; Lukáč, M.; Pajtinková Bartáková, G.

Conceptual Comparison of Internal Audit and Internal Control in the Marketing Environment.

Sustainability 2021, 13, 6691

https://doi.org/10.3390/su13126691

Academic Editors: Ionel Bostan and Marc A. Rosen

Received: 26 April 2021

Accepted: 9 June 2021

Published: 12 June 2021

Publisher's Note: MDPI stays neutral with regard to jurisdictional claims in published maps and institutional affiliations.

Copyright: () 2021 by the authors. Licensee MDPI, Basel, Switzerland. This article is an open access article distributed under the terms and conditions of the Creative Commons Attribution (CC BY) license (https:// creativecommons.org/licenses/by/ $4.0 /)$.

\begin{abstract}
There is a conceptual problem in the adequate application of internal audit and internal control in the real business of the marketing environment. Although both of these managerial tools are theoretically defined, they are practically interchangeable in business. This limits their application. It is therefore necessary to focus on both concepts and make the theory and practice more precise or remove any overlaps. The aim of this paper is therefore a theoretical and practical comparison of internal audit and internal control concepts in the marketing environment. To fulfil this purpose and verify the hypotheses, this paper uses computer assisted self interviewing. The research was conducted in Q1 2021 with a sample of 3052 small and medium enterprises from the international environment of the EU 27. The research conclusions show a strong correlation of the theoretical perception of the terms of internal audit and internal control. At the same time, they show a weak correlation with the audit and control tools used in practice. They also define audit as planned independent assurance (soft consultation) and control as operational managerial assurance (hard comparison). This defines and clarifies scientific theories for managerial practice, thus enhancing and increasing the efficiency of internal audits and internal control in the business environment.
\end{abstract}

Keywords: CASI; correlation; internal audit; internal control; management; marketing

JEL Classification: M420; M12; M14; M15; 310

\section{Introduction}

An integral part of sustainable economies is the marketing environment [1,2]. The processes of supply and demand intermingle with the support of modern marketing approaches [3]. The marketing environment is divided by Kalieva et al. [4] into the Microenvironment and the Macroenvironment. Al-Waely [5] includes customers and organizations in the Microenvironment, while the Macroenvironment mainly includes the economic, technological, legal, and cultural environment. Mose and Syaifuddin [6] subsequently state on this problem that the monitoring of the marketing environment is strategic and necessary.

The concepts of internal auditing and internal control can be applied to monitoring, according to the definition of a professional organization. The Institute of Internal Auditors (IIA) [7] defines the audit concept as follows: "Internal auditing is an independent, objective assurance and consulting activity designed to add value and improve an organization's operations". The Committee of Sponsoring Organizations of the Treadway Commission (COSO) [8] (p. 3) defines the control concept as follows: "Internal control is a process effected by an entity's board of directors, management, and other personnel, designed to 
provide reasonable assurance regarding the achievement of objectives relating to operations, reporting, and compliance".

The internal audit concept (hereinafter "audit") is primarily defined by IIA [7] and by Furtună and Ciucioi [9], while the internal control concept (hereinafter "control") is primarily defined by COSO [8] and by Lobo et al. [10]. Audit and control are two theoretical concepts (see H1) [11]. In practice, however, both concepts may be combined into one (see H2), defined inaccurately on a conceptual level, or merged. This occurs due to local translation where the term "control" is explicitly translated using the term "audit" [12]. Ultimately, there may be overlap in explaining both concepts, see Váchal et al. [13], which defines audit as control, hence the chaos.

The chaos in theory then moves into practice as well. If the audit and control concepts are combined into one at the theoretical level [13], they can be combined at the practical level as well (see H3). Although both concepts can gain knowledge from each other, they should always be applied correctly. Thus, audit concepts should be applied for audit purposes, and control concepts for control purposes; for management [14], the application of the right concept to processes is crucial $[15,16]$, particularly in the expansive and risky marketing environment [17] (see below). Management [18,19] applies control concepts [20] rather than audit concepts [21] (see H4).

Depending on the presentation of the issue, research questions or problems arise here: Q1/P1 descriptive -What audit and control concepts are used? Q2/P2 relational - What is the conceptual relationship between audit and control? The aim of this paper (A1) is therefore a theoretical and practical comparison of internal audit and internal control concepts in the marketing environment. The achievement of this aim will shed light on the following hypotheses:

Hypothesis 1 (H1). The theoretical concepts of audit and control differ (see $[7,8])$.

Hypothesis 2 (H2). There is a significant correlation between the concepts of audit and control.

Hypothesis 3 (H3). The practical application of audit and control uses these concepts interchangeably.

Hypothesis 4 (H4). Implementation of the control concept takes place more often than implementation of the audit concept.

\section{Literature Review}

This chapter presents the author's selection of initial literature on the issue examined and the current state of the issues. The text focuses on the concepts of audit and control [22,23], especially in the European context of the current marketing environment of SMEs. The marketing environment is full of risks (Risk of enterprise products lowering demand; Risk of enterprise imperfect pricing policy; Risk of enterprise low-quality products; Risk of enterprise low degree products sales promotion) [24] (p. 231). Risks threaten this environment $[25,26]$ and make it difficult to achieve business goals $[27,28]$. To mitigate these risks [29], it is necessary to use the right audit concepts and control concepts (the concepts stand for theories, principles, and models). The precise definition of audit and control, including historical and etymological definition, is therefore the basis of this research.

Audit [30] is etymologically, procedurally, and conceptually based on the Latin word "audire" which means "to listen" or "to hear" [31,32]. The term is derived primarily from the historical theories of the Roman Empire: theories about soldiers, where officers would listen to the complaints of the soldiers [33]; theories about officials, where one listened to a reading of the other's accounting [34,35]; theories about the administrators whose reports on management were followed [36]; and theories about auditors, who listened to accountants when investigating live practices $[37,38]$. The audit concept is primarily based on soft communication methods. 
Control [39] differs from audit etymologically, and therefore also procedurally and conceptually. It is based on the Latin "contra" and "rotulus" which mean "opposite" and "a

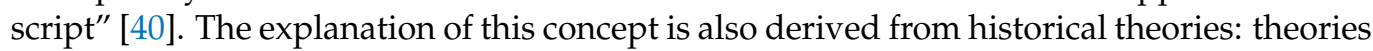
about employees who play a role and follow a script [40]; theories about accountants who reconcile records against identical accounting records [41]; or theories about actors, where one follows a script and the other monitors role compliance [42,43]. The control concept is therefore primarily based on hard comparison methods.

Both audit and control concepts also need to be put into the current marketing environment. Anchoring the concept of audit in the marketing context today is presented by Kitchenko and Kuchina [44], as a study of the activities of an enterprise in order to develop a proposal for drawing up an action plan aimed at increasing the efficiency of the enterprise's marketing. In contrast, control in the marketing context is today defined as monitoring, directing, and evaluating to ensure that the marketing plan is implemented as envisioned and, when it is not, corrective action is taken [45]. Based on this text, the H1 hypothesis will be verified after the whole research is fully completed.

\section{Materials and Methods}

The materials studied are the audit concepts by Furtună and Ciucioi [9] and the control concepts by Lobo et al. [10]. As part of answering research questions and elaborating the objective, the selected hypotheses (particularly H1) are methodically processed using literary research and content analysis. Literature review [46] is defined in this research as a summary of knowledge about the subject of research based on the study of the literature. Content analysis [47] focuses on the occurrence of certain concepts in the text and subsequently also on the relationships between these occurrences (the choice of the words "audit" and "control" in peer-reviewed texts younger than the year 2000). The recorded results are summarized below.

The terms audit and control are specifically situated in the European marketing environment of SMEs. SMEs are the backbone of the marketing environment in today's world and especially in the economy and Industry 4.0, as mentioned by Ferreira et al. [48], Kosacka-Olejnik and Pitakaso [49], and Garbellano and Da Veiga [50]. This economic environment has been purposefully narrowed down to the marketing environment according to Godwin [3]. The marketing environment is dynamic, volatile, and affected by a number of ongoing changes [51,52]. The research presented is therefore materially focused on defined enterprises (SMEs) in a defined environment (marketing environment).

Subsequently, the hypotheses are verified using the CASI method (Computer Assisted Self Interviewing) by Raffaelli et al. [53]. The CASI Questionnaire (link) was delivered via e-mail. The e-mail was addressed to TOP management (directors, owners, head of departments). The European Amadeus database by Bureau van Dijk was used to select the data [54]. From this database, the selection was made using filters according to the paper topic of respondents, i.e., $n_{0}=21,372$ (the core set) of SMEs as defined by Commission Recommendation 2003/361/EC from the marketing environment doing business in the EU 27 (i.e., without the UK). A CASI questionnaire (Google form) was sent to the aforementioned set $n_{0}$ with prepared questions from the areas of audit and control (see Table 1). After that, in the first quarter of 2021, a total of $n=3052$ (control sample according to the specifications of Tables 2 and 3) of complete answers were obtained, the data of which were statistically analysed. Return on Equity (ROE) was used to establish what impact the use of auditing and control had on a company's performance. 
Table 1. CASI questionnaire.

\begin{tabular}{|c|c|c|c|c|}
\hline No & Concept & Hypothesis & Table & Question \\
\hline Q1 & \multirow{3}{*}{ General } & $\mathrm{N} / \mathrm{A}$ & 2 & Turnover size at $n$ ? \\
\hline Q2 & & $\mathrm{N} / \mathrm{A}$ & 3 & Number of employees at $n$ ? \\
\hline Q3 & & H1 & 4 & $\begin{array}{l}\text { Do you perceive a difference between audit and } \\
\text { control? }\end{array}$ \\
\hline Q4 & \multirow{4}{*}{ Audit } & $\mathrm{H} 4$ & 9 & Are you practicing audit? \\
\hline Q5 & & $\mathrm{H} 1$ & 5 & What do you imagine under the "audit" concept? \\
\hline Q6 & & H3 & 8 & What audit tools do you use? \\
\hline Q7 & & $\mathrm{H} 4$ & 10 & How much did you invest in the audit in $2019 ?$ \\
\hline Q8 & \multirow{4}{*}{ Control } & $\mathrm{H} 4$ & 9 & Are you practicing control? \\
\hline Q9 & & H1 & 6 & What do you imagine under the "control" concept? \\
\hline Q10 & & H3 & 8 & What control tools do you use? \\
\hline Q11 & & $\mathrm{H} 4$ & 10 & How much did you invest in the control in $2019 ?$ \\
\hline
\end{tabular}

Table 2. Q1-Turnover (in EUR x 1000) size at $n$ ?

\begin{tabular}{ccccc}
\hline & & Frequency & Percent & Cumulative Percent \\
\hline \multirow{7}{*}{ Valid } & $0-5000$ & 126 & 4.1 & 4.1 \\
\cline { 2 - 5 } & $5-10,000$ & 405 & 13.3 & 17.4 \\
\cline { 2 - 5 } & $10-25,000$ & 1230 & 40.3 & 57.7 \\
\cline { 2 - 5 } & $25-50,000$ & 534 & 17.5 & 75.2 \\
\cline { 2 - 5 } & $50-100,000$ & 296 & 9.7 & 84.9 \\
\hline & $100-250,000$ & 379 & 12.4 & 97.3 \\
\hline $250-500,000$ & 70 & 2.3 & 99.6 \\
\hline $500-1,000,000$ & 12 & 0.4 & 100.0 \\
\hline & Total & 3052 & 100.0 & \\
\hline
\end{tabular}

Source: Research data, authors proceeding, SPSS ver. 25.

Table 3. Q2-Number of employees at $\mathrm{n}$ ?

\begin{tabular}{ccccc}
\hline & & Frequency & Percent & Cumulative Percent \\
\hline \multirow{3}{*}{ Valid } & $0-5$ & 846 & 27.7 & 27.7 \\
\cline { 2 - 5 } & $6-15$ & 808 & 26.5 & 54.2 \\
\cline { 2 - 5 } & $16-30$ & 667 & 21.9 & 76.0 \\
\cline { 2 - 5 } & $31-50$ & 512 & 16.8 & 92.8 \\
\cline { 2 - 5 } & $51-100$ & 97 & 3.2 & 96.0 \\
\hline & $101-250$ & 122 & 4.0 & 100.0 \\
\hline
\end{tabular}

Source: Research data, authors proceeding, SPSS ver. 25.

The reliability and consistency of the analysed data are examined according to Cronbach's alpha $[55,56]$. Cronbach's alpha takes values in the range $0-1$, where values above 0.7 show high reliability and data consistency [57,58]. After that, the values of linear dependence and strength of the selected variables are tested according to Pearson's correlation $[59,60]$. The minimum values of Pearson's correlation coefficient were determined for data analysis as 0.4 and higher by Evans [61]. For the research overview, the models 
for audit and control concepts were computed using the stepwise regression procedure. In some cases, frequency analysis by Darlington and Hayes [62] is used for comparison and interpretation.

The final step of data analysis was the stepwise regression method, which was used to construct the managerial HR competencies model, and the analysis of other data methods. All output results and models were tested for significance. The value for passing this test was set at a level of 5\%. The detail and information according to Darlington and Hayes [62] and the IBM SPSS ver. 25 user manual.

\section{Results}

The initial step of the study was to perform a test of the reliability and consistency of the data examined using the Cronbach alpha calculation method. Here, the minimum test value was set at 0.7 . The examined sample of 11 variables (see Table 1$)+$ ROE passed this test and reached a Cronbach's alpha value of 0.816 . This result demonstrates high reliability of the investigated data and supports the conclusions of the data analysis for the evaluation of hypotheses $\mathrm{H} 1$ to $\mathrm{H} 4$. The following results are presented in the text according to the verification of individual hypotheses.

\subsection{H1-Theoretical Concepts of Audit and Control Differ}

The first result is to verify the differences between the two concepts as used by management. From the above theoretical perspective and literature analyses, it is clear that the concepts of audit and control are different. It can be deducted from the analyses that, in addition to minor differences, the major differences are mainly in timing (audit is planned; control is operational), responsibility (audit and the auditor; control and the manager). A practical view of the differences between the concepts is captured in the frequency analysis of the examined variables in Tables 3-5, which verifies theoretically and practically that the basic concepts of audit and control are different. It is interesting to note that according to Table $4,47.2 \%$ of respondents claimed they perceived audit and control as two different concepts, $37.2 \%$ of respondents said that these two concepts were partly different, and only $16.6 \%$ understood audit and control as a single approach. This confirms H1.

Table 4. H1—Do you perceive a difference between audit and control?

\begin{tabular}{ccccc}
\hline \multirow{3}{*}{ Valid } & & Frequency & Percent & Cumulative Percent \\
\hline & no & 476 & 15.6 & 15.6 \\
\cline { 2 - 5 } & partly & 1134 & 37.2 & 52.8 \\
\cline { 2 - 5 } & yes & 1442 & 47.2 & 100.0 \\
\cline { 2 - 5 } & Total & 3052 & 100.0 & \\
\hline
\end{tabular}

Source: Research data, authors proceeding, SPSS ver. 25.

Table 5. H1-What do you imagine under the "audit" concept?

\begin{tabular}{ccccc}
\hline & & Frequency & Percent & Cumulative Percent \\
\hline \multirow{3}{*}{ Valid } & Nothing & 212 & 6.9 & 6.9 \\
\cline { 2 - 5 } & Check & 704 & 23.1 & 30.0 \\
\cline { 2 - 5 } & bureaucracy & 884 & 29.0 & 59.0 \\
\cline { 2 - 5 } & Help & 726 & 23.8 & 82.8 \\
\cline { 2 - 5 } & Consultation & 430 & 14.1 & 96.9 \\
\cline { 2 - 5 } & Other & 96 & 3.1 & 100.0 \\
\hline
\end{tabular}

Source: Research data, authors proceeding, SPSS ver. 25. 
Tables 5 and 6 show that companies that have started using audit and control mostly just use the control concept and regard the audit concept as a more advanced discipline. When analysing the data in Tables 5 and 6, we can conclude that the investigated companies understand the concepts of audit and control as more or less positive actions that enhance a company's performance and efficiency. Neither concept is perceived as repressive by the majority of respondents. What is definitely positive is the frequency of the notions of "help, consultation" which in the case of the audit concept was 37.9\%, while in the case of the control concept the percentage was 35.5\%. One interesting finding is the perception of audit $(17.7 \%)$ and control $(29 \%)$ as bureaucratic. A tighter focus on this finding shows the frequency of responses by SME size in Table 3 and found that the results follow the values in Tables 5 and 6 within $+/-6 \%$, regardless of the size of the SME by number of employees. The authors see the results as a question of the company culture, where some employees follow their own goals against the enterprise ones.

Table 6. H1-What do you imagine under the "control" concept?

\begin{tabular}{ccccc}
\hline & & Frequency & Percent & \multicolumn{2}{c}{ Cumulative Percent } \\
\hline & Nothing & 88 & 2.9 & 2.9 \\
\cline { 2 - 5 } & Check & 818 & 26.8 & 65.1 \\
\cline { 2 - 5 } Valid & bureaucracy & 539 & 17.7 & 24.8 \\
\cline { 2 - 5 } & Consultation & 418 & 21.8 & 38.3 \\
\cline { 2 - 5 } & Other & 525 & 13.7 & 100.0 \\
\hline
\end{tabular}

Source: Research data, authors proceeding, SPSS ver. 25.

\subsection{H2-There Is a Significant Correlation between the Concepts of Audit and Control}

Another result is a theoretical approach to audit and control in an international context. The word "audit" is translated from English as "audit" [34]. In contrast, the translation of the word "control" is not so unambiguous. It can be rendered as "check", "inspection", "supervision", etc. [12], which may lead to inaccuracies. Some authors use "audit" and "control" as synonyms $[63,64]$. This can theoretically confirm the correlation of both concepts. The mutual correlation of both concepts (H2) is also confirmed by calculating Pearson's correlation coefficient and the value of linear dependence between the examined variables (see Table 7).

Table 7 offers some interesting findings. One of them is the negative correlation between Q11 (How much did you invest in control in 2019?) and Q4 (Do you practice auditing?) - 0.013, and also Q6 (What audit tools do you use?) - 0.010. Although the value of these negative correlations is not very significant, the very existence of negative correlations suggests that the higher usage of the audit concept reduces the frequency of implementation of the control concept.

The correlation detected between Q2 (Number of employees at n?) and Q5 (What do you imagine under the concept of "auditing"?) 0.465 and Q9 (What do you imagine under the concept of "control"?) 0.492 is interesting. These values can be interpreted as indicating that the use of the concepts of audit and control increases with the number of employees at the company. 
Table 7. H2-Variables Pearson Correlations.

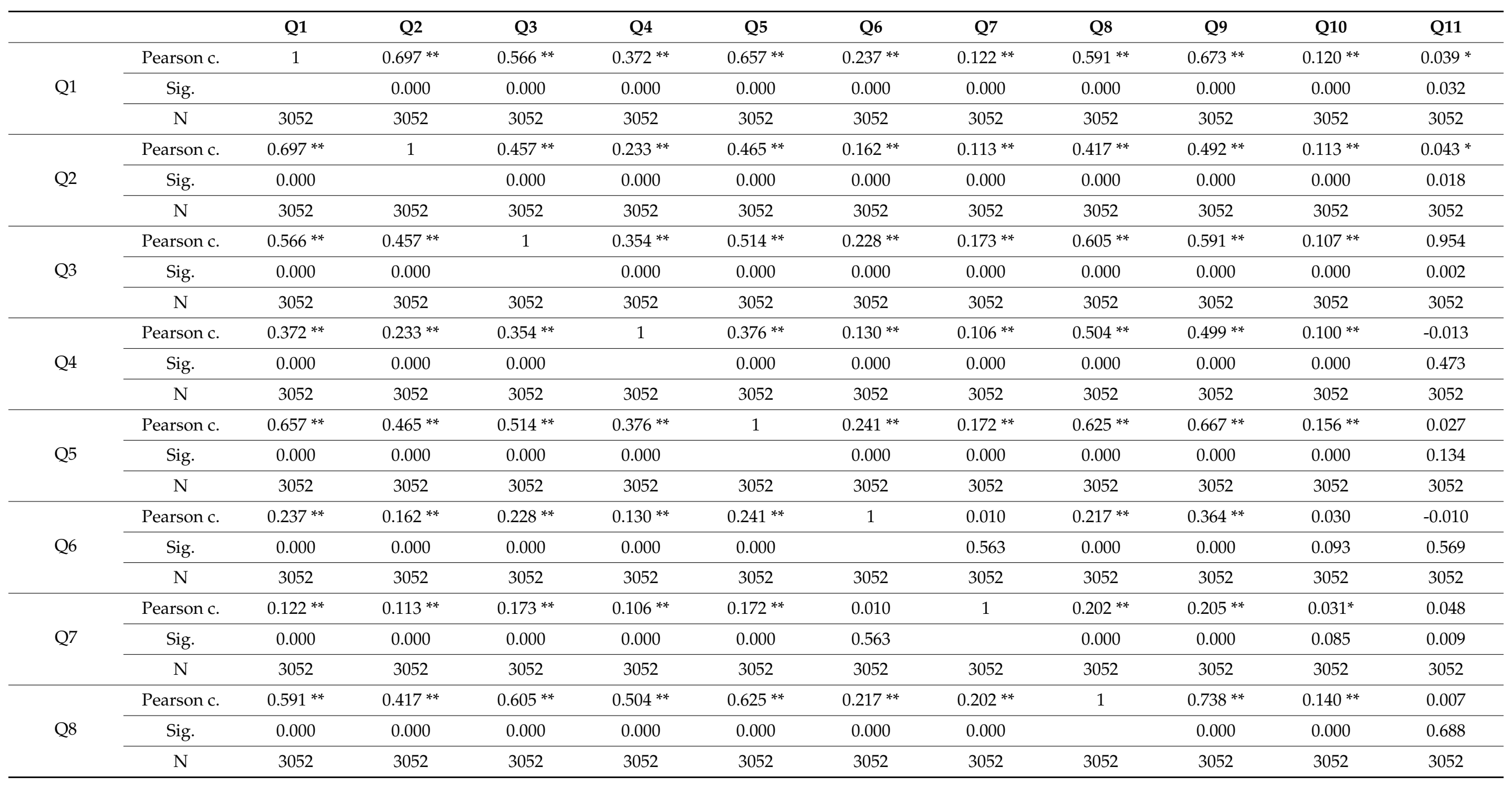


Table 7. Cont.

\begin{tabular}{|c|c|c|c|c|c|c|c|c|c|c|c|c|}
\hline & & Q1 & Q2 & Q3 & Q4 & Q5 & Q6 & Q7 & Q8 & Q9 & Q10 & Q11 \\
\hline \multirow[b]{2}{*}{ Q9 } & Pearson c. & $0.673 * *$ & $0.492^{* *}$ & $0.591 * *$ & $0.499 * *$ & $0.667^{* *}$ & $0.364^{* *}$ & $0.205^{* *}$ & $0.738^{* *}$ & 1 & $0.155^{* *}$ & 0.017 \\
\hline & Sig. & 0.000 & 0.000 & 0.000 & 0.000 & 0.000 & 0.000 & 0.000 & 0.000 & & 0.000 & 0.350 \\
\hline \multirow{3}{*}{ Q10 } & Pearson c. & $0.120 * *$ & $0.113^{* *}$ & $0.107^{* *}$ & $0.100^{* *}$ & $0.156^{* *}$ & 0.030 & 0.031 & $0.140 * *$ & $0.155^{* *}$ & 1 & $0.360^{* *}$ \\
\hline & Sig. & 0.000 & 0.000 & 0.000 & 0.000 & 0.000 & 0.093 & 0.085 & 0.000 & 0.000 & & 0.000 \\
\hline & $\mathrm{N}$ & 3052 & 3052 & 3052 & 3052 & 3052 & 3052 & 3052 & 3052 & 3052 & 3052 & 3052 \\
\hline \multirow{3}{*}{ Q11 } & Pearson c. & 0.039 * & $0.043 *$ & 0.001 & -0.013 & 0.027 & -0.010 & $0.048^{* *}$ & 0.007 & 0.017 & $0.360 * *$ & 1 \\
\hline & Sig. & 0.032 & 0.018 & 0.954 & 0.473 & 0.134 & 0.569 & 0.009 & 0.688 & 0.350 & 0.000 & \\
\hline & $\mathrm{N}$ & 3052 & 3052 & 3052 & 3052 & 3052 & 3052 & 3052 & 3052 & 3052 & 3052 & 3052 \\
\hline
\end{tabular}


Additionally, the higher value of correlation between Q1 (Turnover size at n?) and Q3 (Do you see a difference between audit and control?) 0.566, Q5 (What do you imagine under the concept of "auditing"?) 0.657, Q8 (Do you practice control?) 0.591, and Q9 (What do you imagine under the concept of "control"?) 0.673 should be pointed out. These values suggest a significant rate of linear dependence (the correlation coefficient) between the studied variables. A possible interpretation of this finding is that the higher a company's turnover, the more important the use of the concepts of audit and control. These findings further support the conclusions made for models (1) and (2).

Correlation analysis of the relationship between Q4 (Do you practice auditing?) and Q7 (How much did you invest in auditing in 2019?) 0.106 provides further interesting findings. This low level of correlation suggests that the use of the audit concept in companies is not significantly linked to how much money is invested in auditing. It can thus be concluded that auditing is a low-cost tool through which companies can increase their competitiveness and efficiency. We reached a similar finding when interpreting the level of correlation between Q11 (How much did you invest in control in 2019?) and Q8 (Do you practice control?) 0.007 . This level of correlation means that there is almost no relationship between the costs and use of the control concept. Thus, as in the case of the audit concept, it can be concluded that the control concept is a low-cost tool for companies to increase their competitiveness and efficiency. It can be expected that more extensive use of the concepts of audit and control regardless of financial resources will lead to their more frequent use in the operation of companies. This would in turn mean that both concepts will transition over time from statistical concepts to dynamic ones.

Table 7 provides the main results of the study and the existing correlations between the concepts of audit and control (H2). To verify this hypothesis (H2), the following Pearson's correlation values were intentionally selected from these results: the result of Q5 and Q9 (0.667) above all indicates an important correlation between the theoretical perception of the concepts of audit and control. Secondly, however, it is necessary to analyse the result of Q6 and Q10 (0.030), which shows a very weak correlation between the audit and control tools used in practice. These facts can be interpreted as meaning that although respondents perceive audit and control similarly (theory), they use different tools for both concepts (practice). This confirms $\mathrm{H} 2$.

\subsection{H3-The Practical Application of Audit and Control Uses These Concepts Interchangeably}

As can be seen from Table 7, the results from Q6 and Q10 (0.030) show a very weak correlation between the audit and control methods used (here it is worth repeating that the study examined SMEs in the marketing environment). It is clear that in the case of audit and control tools we distinguish between their applications. The table and frequency analysis below only confirm this result. Audit concepts focus mainly on the application of methods related to questioning and observation (Table 8, Audit section). Control concepts focus mainly on the application of methods related to analytics and statistics (Table 8 , Control section). These results align with the results of the literature review, that audit is based on soft communication methods and control on hard comparative methods. This refutes $\mathrm{H} 3$.

\subsection{H4-Implementation of the Control Concept Takes Place More Often Than Implementation of the Audit Concept}

The latest results concern the frequency with which both concepts are used. This fact cannot be verified theoretically. Therefore, it is necessary to focus on the practical results of the survey. It is quite clear that the frequency of application of the control concept (Table 9, Control section) is higher than the frequency of application of the audit concept (Table 9 , Audit section). Furthermore, the correlation of 0.504 is significant at $1 \%$ (Table 7 ), which indicates an important level of linear dependence (correlation). This confirms that the control concept is applied in practice more often than the audit concept, thereby validating H4. This issue is also illustrated by the volume of estimated investments (Table 10) in 
both concepts (however it is not possible to quantify investments exactly given the scale of the inquiries).

Table 8. H3-What audit tools (Q6)/ control tools (Q10) do you use?

\begin{tabular}{cccccccc}
\hline & & \multicolumn{2}{c}{ Frequency } & \multicolumn{2}{c}{ Percent } & \multicolumn{2}{c}{ Cumulative Percent } \\
\hline \multirow{7}{*}{ Valid } & Audit & Control & Audit & Control & Audit & Control \\
\hline \multirow{7}{*}{ Nothing } & 277 & 629 & 9.1 & 20.6 & 9.1 & 20.6 \\
\cline { 2 - 8 } & Analytic & 967 & 1171 & 31.7 & 38.4 & 40.8 & 59.0 \\
\cline { 2 - 8 } & Statistic & 799 & 949 & 26.2 & 31.1 & 66.9 & 90.1 \\
\cline { 2 - 8 } & Requesting & 530 & 280 & 17.4 & 9.2 & 84.3 & 99.2 \\
\cline { 2 - 8 } & Observing & 307 & 12 & 10.1 & 0.4 & 94.4 & 99.6 \\
\cline { 2 - 7 } & Other & 172 & 11 & 5.6 & 0.4 & 100.0 & 100.0 \\
\cline { 2 - 7 } & Total & 3052 & 3052 & 100.0 & 100.0 & & \\
\hline
\end{tabular}

Source: Research data, authors proceeding, SPSS ver. 25.

Table 9. H4-Do you use audit (Q4)/ control (Q8)?

\begin{tabular}{cccccccc}
\hline & & \multicolumn{2}{c}{ Frequency } & \multicolumn{2}{c}{ Percent } & \multicolumn{2}{c}{ Cumulative Percent } \\
\hline \multirow{3}{*}{ Valid } & Audit & Control & Audit & Control & Audit & Control \\
\cline { 2 - 8 } & No & 1036 & 426 & 33.9 & 14.0 & 33.9 & 14.0 \\
\cline { 2 - 8 } & partly & 1219 & 991 & 39.9 & 32.5 & 73.9 & 46.4 \\
\cline { 2 - 8 } & full & 797 & 1635 & 26.1 & 53.6 & 100.0 & 100.0 \\
\cline { 2 - 8 } & Total & 3052 & 3052 & 100.0 & 100.0 & & \\
\hline
\end{tabular}

Source: Research data, authors proceeding, SPSS ver. 25.

Table 10. H4-How much did you invest in audit (Q7)/control (Q11) in 2019 (EUR)?

\begin{tabular}{|c|c|c|c|c|c|c|c|}
\hline & & \multicolumn{2}{|c|}{ Frequency } & \multicolumn{2}{|c|}{ Percent } & \multicolumn{2}{|c|}{ Cumulative Percent } \\
\hline & & Audit & Control & Audit & Control & Audit & Control \\
\hline \multirow{6}{*}{ Valid } & to 500 & 908 & 1447 & 29.8 & 47.4 & 29.8 & 47.4 \\
\hline & $501-1000$ & 897 & 1196 & 29.4 & 39.2 & 59.1 & 86.6 \\
\hline & $\begin{array}{c}1001 \text { to } \\
5000\end{array}$ & 835 & 339 & 27.4 & 11.1 & 86.5 & 97.7 \\
\hline & $\begin{array}{c}5001 \text { to } \\
10,000\end{array}$ & 315 & 21 & 10.3 & 0.7 & 96.8 & 98.4 \\
\hline & $\begin{array}{c}\text { up to } \\
10,001\end{array}$ & 97 & 49 & 3.2 & 1.6 & 100.0 & 100.0 \\
\hline & Total & 3052 & 3052 & 100.0 & 100.0 & & \\
\hline
\end{tabular}

Source: Research data, authors proceeding, SPSS ver. 25.

As a final analysis step for the audit and control comparison, the models were compounded using stepwise regression (see Tables 11 and 12). 
Table 11. The control model ${ }^{\mathrm{a}}$.

\begin{tabular}{|c|c|c|c|c|c|c|}
\hline & \multirow[t]{2}{*}{ Model } & \multicolumn{2}{|c|}{$\begin{array}{l}\text { Unstandardized } \\
\text { Coefficients }\end{array}$} & \multirow{2}{*}{$\begin{array}{c}\text { Standardized } \\
\text { Coefficients }\end{array}$} & \multirow[t]{2}{*}{$t$} & \multirow[t]{2}{*}{ Sig. } \\
\hline & & B & Std. Error & & & \\
\hline \multirow{2}{*}{1} & (Constant) & 1.894 & 0.037 & & 51.624 & 0.000 \\
\hline & Q9 & 0.330 & 0.011 & 0.464 & 28.915 & 0.000 \\
\hline \multirow{3}{*}{2} & (Constant) & 1.771 & 0.038 & & 46.713 & 0.000 \\
\hline & Q9 & 0.202 & 0.017 & 0.284 & 12.140 & 0.000 \\
\hline & Q8 & 0.351 & 0.034 & 0.244 & 10.437 & 0.000 \\
\hline \multirow{4}{*}{3} & (Constant) & 1.816 & 0.039 & & 46.473 & 0.000 \\
\hline & Q9 & 0.223 & 0.017 & 0.313 & 12.946 & 0.000 \\
\hline & Q8 & 0.400 & 0.035 & 0.278 & 11.357 & 0.000 \\
\hline & Q3 & -0.132 & 0.029 & -0.093 & -4.523 & 0.000 \\
\hline \multirow{5}{*}{4} & (Constant) & 1.885 & 0.041 & & 45.496 & 0.000 \\
\hline & Q9 & 0.244 & 0.018 & 0.342 & 13.788 & 0.000 \\
\hline & Q8 & 0.404 & 0.035 & 0.281 & 11.490 & 0.000 \\
\hline & Q3 & -0.100 & 0.030 & -0.070 & -3.350 & 0.001 \\
\hline & Q2 & -0.069 & 0.014 & -0.090 & -4.871 & 0.000 \\
\hline
\end{tabular}

a Dependent Variable: ROE. Source: Research data, authors proceeding, SPSS ver. 25.

Table 12. The audit model ${ }^{\mathrm{a}}$.

\begin{tabular}{|c|c|c|c|c|c|c|}
\hline & \multirow[t]{2}{*}{ Model } & \multicolumn{2}{|c|}{$\begin{array}{l}\text { Unstandardized } \\
\text { Coefficients }\end{array}$} & \multirow{2}{*}{$\begin{array}{c}\begin{array}{c}\text { Standardized } \\
\text { Coefficients }\end{array} \\
\text { Beta }\end{array}$} & \multirow[t]{2}{*}{$t$} & \multirow[t]{2}{*}{ Sig. } \\
\hline & & B & Std. Error & & & \\
\hline \multirow{2}{*}{1} & (Constant) & 2.158 & 0.036 & & 59.673 & 0.000 \\
\hline & Q5 & 0.304 & 0.014 & 0.363 & 21.532 & 0.000 \\
\hline \multirow{3}{*}{2} & (Constant) & 2.054 & 0.037 & & 55.924 & 0.000 \\
\hline & Q5 & 0.242 & 0.015 & 0.290 & 16.210 & 0.000 \\
\hline & Q4 & 0.263 & 0.024 & 0.196 & 10.964 & 0.000 \\
\hline \multirow{4}{*}{3} & (Constant) & 2.005 & 0.040 & & 50.134 & 0.000 \\
\hline & Q5 & 0.220 & 0.017 & 0.263 & 13.234 & 0.000 \\
\hline & Q4 & 0.248 & 0.024 & 0.185 & 10.135 & 0.000 \\
\hline & Q3 & 0.086 & 0.028 & 0.060 & 3.053 & 0.002 \\
\hline \multirow{5}{*}{4} & (Constant) & 2.038 & 0.043 & & 47.492 & 0.000 \\
\hline & Q5 & 0.231 & 0.017 & 0.276 & 13.287 & 0.000 \\
\hline & Q4 & 0.249 & 0.024 & 0.185 & 10.168 & 0.000 \\
\hline & Q3 & 0.103 & 0.029 & 0.072 & 3.527 & 0.000 \\
\hline & Q2 & -0.032 & 0.015 & -0.041 & -2.122 & 0.034 \\
\hline
\end{tabular}

a Dependent Variable: ROE. Source: Research data, authors proceeding, SPSS ver. 25.

Based on Table 11, the Control model and its influence for enterprise performance for the dependent variable ROE is: 
Model 1

$\mathrm{ROE}=1.885 *$ Constant $+0.244 * \mathrm{Q} 9$ (What do you imagine under the concept of "control"?) $+0.404 * \mathrm{Q} 8$ (Are you practicing control?) $+-0.100 * \mathrm{Q} 3$ (Do you perceive a difference between audit and control?) $+-0.069 * \mathrm{Q} 2$ (Number of employees)

This model shows the "weight" of all variables entered into the model and their importance. The model is significant at $1 \%$. Closer model 1 computing results see Tables A1 and A2.

Based on Table 12, the Audit model and its influence for enterprise performance for the dependent variable ROE is:

Model 2

$\mathrm{ROE}=2.038 *$ Constant $+0.231 * \mathrm{Q} 5$ (What do you imagine under the concept of "auditing"?) $+0.249 * \mathrm{Q} 4$ (Do you practice auditing?) $+0.103 * \mathrm{Q} 3$ (Do you see a difference between auditing and control?) $+{ }^{*}-0.032 * \mathrm{Q} 2$ (Number of employees)

This model shows the "weight" of all variables entered into the model and their importance. The model is significant at $5 \%$. Closer model 1 computing results see Tables A3 and A4.

The two models 1 and 2 defined show a higher value of constants 6 (2.038) and 5 (1.885). This constant represents unknown variables (not included in the research)-i.e., factors that impact ROE trends. This finding was expected as a number of internal and external factors other than audit and control impact a company's performance.

In the control model 1 , the value of -0.100 of the variable Q3 (Do you see a difference between auditing and control?) is worth noting. This negative value implies that in the case of companies that mainly use the control concept, the attempt to distinguish between the concepts of auditing and control leads to a negative (low) impact on increased ROE. However, this impact is usually only temporary and is later replaced by a positive impact on ROE according to model 2. In model 2, the value 0.103 of the variable Q3 (Do you see a difference between auditing and control?) is positive and supports increased ROE. In connection with the conclusions of model 1 and Tables 7 and 9, it is evident that when they start using the concepts of audit and control, companies at first prefer the control concept. This trend is then replaced with the use of both concepts (with a temporary negative impact on ROE). Models 1 and 2 show that the joint use of the audit and control concepts has a positive impact on the company's performance represented by the dependent variable ROE.

The fact that the variable Q2 (Number of employees) has a negative (low) value in both models 1 and 2 is yet another noteworthy finding. This fact can be interpreted as implying that as the number of employees increases, the importance of the concepts of audit and control as a factor supporting increased ROE slightly decreases. This should be interpreted in connection with the law of diminishing returns.

\section{Discussion}

The results are an important probe for modern management $[65,66]$. Concepts, methods, and approaches that have been used for a long time are evolving. It is therefore necessary to pay attention to this development and make the theory and practice more precise. Here, it can be stated that the conceptual intertwining of audit and control is based on the historical connection of both concepts with accounting [34,41]. However, new developments have transitioned auditing to planned independent assurance (soft consultation) and control to operational management assurance (hard comparison). This audit result is confirmed by Plant et al. [67] and Jokić et al. [68]. For the control, the result is confirmed by Liangcheng et al. [69].

At the same time, the results clearly show that dynamic practice establishes theories that become static and cannot remain current for practice [70,71]. The results show differences in the theoretical concepts of audit and control (H1—confirmed hypothesis), their correlation (H2-confirmed hypothesis), as well as the more frequent application of the 
control concept over the audit concept (H4-confirmed hypothesis). In practice, however, different methods are applied and both research concepts are mixed (H3-refuted hypothesis). This can be interpreted as meaning that the practical application of the concepts is correct, regardless of the theories. The results here refine the theories presented by Furtună and Ciucioi [9] and Lobo et al. [10].

Here, we can discuss the limits of the research presented, which we can see in the accuracy of the results. Precise separation of audit and control, as well as the determination of a correlation, would allow independent measurement, not questioning. Independent measurement, for example in the form of quantification of costs, capacities, or other quantities, is exact. However, such a measurement is difficult to implement over the mediumand long-term and also entails additional costs. Higher accuracy of the measurements performed can be expected with the implementation of a higher form of digitization $[72,73]$ and Industry $4.0[49,74]$. Despite these limits, the results presented refine current knowledge about audit and control.

Throughout the discussion, future perspectives of audit and control in the marketing environment $[75,76]$ can also be outlined. If it is possible to start from the above results, changes can be expected particularly in the timing of both concepts. With the comprehensive digitization of business processes [77,78], planned audits and operational controls will move toward continuous implementation. This has already been confirmed by the theories of Kaban [79] and Bieliaieva [80] about the audit or those of Christensen et al. [81] about control. Audit and control will thus move from partially static concepts to fully dynamic concepts $[82,83]$. Both concepts will enable management to provide online assurance about ongoing processes as well as online elimination of process risks $[84,85]$. This, in turn, will increase managerial efficiency, enterprise performance, and stability [86,87].

\section{Conclusions}

The objective of this paper (A1) is a theoretical and practical comparison of internal audit and internal control concepts in the marketing environment. To fulfil this goal, CASI polling is used on a sample of $n=3052$ EU 27 SMEs. Cronbach's alpha and Pearson's correlation methods are also used. From the results presented it is possible to read the answers to the questions raised and the problems recorded (Q1/P1, Q2/P2). The research and data presented show an important correlation between the theoretical perception of the concepts of internal audit and internal control (H2 and Table 7). At the same time, they show a very weak correlation between the audit and control tools used in practice (H2 and Table 7). The final analysis step was to compile audit and control models for the dependent variable ROE. These models point to the variables "weight" and importance for enterprise performance and competitiveness. Both models should be used for audit and control concepts with increased emphasis on ROE. Moreover, they define audit as planned independent assurance (soft consultation) and control as operational managerial assurance (hard comparison). These results complement industry and conceptual findings related to internal audit and control $[9,10]$. This clarifies scientific research theories for managerial practice. Both concepts need to be addressed on a continuous basis. It is possible to focus mainly on the digitization of these concepts and their agile transformation from partially dynamic/online concepts to fully dynamic/online concepts.

Author Contributions: Conceptualization, V.K.; methodology, P.P.; software, P.P.; validation, M.L. and G.P.B., formal analysis, M.L. and G.P.B.; investigation, P.P.; resources, V.K.; data curation, P.P.; writing-original draft preparation, V.K. and P.P.; writing-review and editing, M.L. and G.P.B.; visualization, P.P.; supervision, V.K.; project administration, M.L.; funding acquisition, M.L. All authors have read and agreed to the published version of the manuscript.

Funding: This research received no external funding.

Institutional Review Board Statement: Not applicable.

Informed Consent Statement: Not applicable. 
Data Availability Statement: Data is contained within the article.

Acknowledgments: The result was created in solving the project “Digital Audit and Risk Management in Industry 4.0" (7427/2020/02 IGA VŠFS) using objective oriented support for specific university research of the University of Finance and Administration.

Conflicts of Interest: The authors declare no conflict of interest.

\section{Appendix A}

Table A1. Model 1 Summary.

\begin{tabular}{cccccccccccc}
\hline \multirow{2}{*}{ Model } & R & R Square & $\begin{array}{c}\text { Adjusted } \\
\text { R Square }\end{array}$ & $\begin{array}{c}\text { Std. Error of the } \\
\text { Estimate }\end{array}$ & $\begin{array}{c}\text { R Square } \\
\text { Change }\end{array}$ & F Change & df1 & $\begin{array}{c}\text { Change Statistics } \\
\text { df2 }\end{array}$ & $\begin{array}{c}\text { Sig. F } \\
\text { Change }\end{array}$ \\
\hline 1 & $0.464^{\mathrm{a}}$ & 0.215 & 0.215 & 0.918 & 0.215 & 836.064 & 1 & 3050 & 0.000 \\
\hline 2 & $0.492^{\mathrm{b}}$ & 0.242 & 0.242 & 0.902 & 0.027 & 108.922 & 1 & 3049 & 0.000 \\
\hline 3 & $0.497^{\mathrm{c}}$ & 0.247 & 0.247 & 0.899 & 0.005 & 20.455 & 1 & 3048 & 0.000 \\
\hline 4 & $0.503^{\mathrm{d}}$ & 0.253 & 0.252 & 0.896 & 0.006 & 23.725 & 1 & 3047 & 0.000 \\
\hline
\end{tabular}

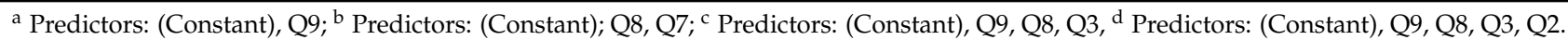

Table A2. Model 1 ANOVA ${ }^{a}$.

\begin{tabular}{|c|c|c|c|c|c|c|}
\hline & Model & Sum of Squares & $\mathrm{df}$ & Mean Square & $F$ & Sig. \\
\hline \multirow{3}{*}{1} & Regression & 704.092 & 1 & 704.092 & 836.064 & $0.000^{b}$ \\
\hline & Residual & 2568.559 & 3050 & 0.842 & & \\
\hline & Total & 3272.651 & 3051 & & & \\
\hline \multirow{3}{*}{2} & Regression & 792.686 & 2 & 396.343 & 487.285 & $0.000^{c}$ \\
\hline & Residual & 2479.965 & 3049 & 0.813 & & \\
\hline & Total & 3272.651 & 3051 & & & \\
\hline \multirow{3}{*}{3} & Regression & 809.217 & 3 & 269.739 & 333.747 & $0.000^{d}$ \\
\hline & Residual & 2463.434 & 3048 & 0.808 & & \\
\hline & Total & 3272.651 & 3051 & & & \\
\hline \multirow{3}{*}{4} & Regression & 828.250 & 4 & 207.063 & 258.108 & $0.000^{\mathrm{e}}$ \\
\hline & Residual & 2444.401 & 3047 & 0.802 & & \\
\hline & Total & 3272.651 & 3051 & & & \\
\hline
\end{tabular}

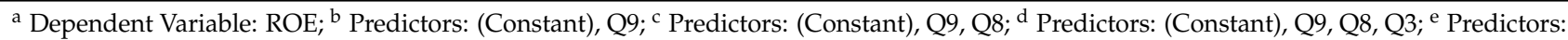
(Constant), Q9, Q8, Q3, Q2; Source: Research data, authors proceeding, SPSS ver. 25.

Table A3. Model 2 Summary.

\begin{tabular}{cccccccccccc}
\hline \multirow{2}{*}{ Model } & R & R Square & $\begin{array}{c}\text { Adjusted } \\
\text { R Square }\end{array}$ & $\begin{array}{c}\text { Std. Error of the } \\
\text { Estimate }\end{array}$ & $\begin{array}{c}\text { R Square } \\
\text { Change }\end{array}$ & F Change & df1 & $\begin{array}{c}\text { Change Statistics } \\
\text { df2 }\end{array}$ & $\begin{array}{c}\text { Sig. F } \\
\text { Change }\end{array}$ \\
\hline 1 & $0.363^{\mathrm{a}}$ & 0.132 & 0.132 & 0.965 & 0.132 & 463.606 & 1 & 3050 & 0.000 \\
\hline 2 & $0.406^{\mathrm{b}}$ & 0.165 & 0.164 & 0.947 & 0.033 & 120.207 & 1 & 3049 & 0.000 \\
\hline 3 & $0.409^{\mathrm{c}}$ & 0.167 & 0.167 & 0.945 & 0.003 & 9.323 & 1 & 3048 & 0.002 \\
\hline 4 & $0.411^{\mathrm{d}}$ & 0.169 & 0.168 & 0.945 & 0.001 & 4.504 & 1 & 3047 & 0.034 \\
\hline
\end{tabular}

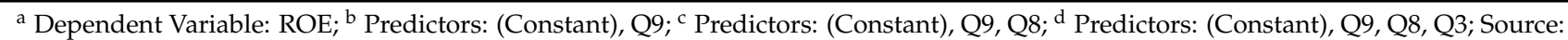
Research data, authors proceeding, SPSS ver. 25. 
Table A4. Model 2 ANOVA a

\begin{tabular}{|c|c|c|c|c|c|c|}
\hline & Model & Sum of Squares & df & Mean Square & $\mathbf{F}$ & Sig. \\
\hline \multirow{3}{*}{1} & Regression & 431.813 & 1 & 431.813 & 463.606 & $0.000^{b}$ \\
\hline & Residual & 2840.838 & 3050 & 0.931 & & \\
\hline & Total & 3272.651 & 3051 & & & \\
\hline \multirow{3}{*}{2} & Regression & 539.566 & 2 & 269.783 & 300.967 & $0.000^{\mathrm{c}}$ \\
\hline & Residual & 2733.085 & 3049 & 0.896 & & \\
\hline & Total & 3272.651 & 3051 & & & \\
\hline \multirow{3}{*}{3} & Regression & 547.900 & 3 & 182.633 & 204.300 & $0.000^{\mathrm{d}}$ \\
\hline & Residual & 2724.751 & 3048 & 0.894 & & \\
\hline & Total & 3272.651 & 3051 & & & \\
\hline \multirow{3}{*}{4} & Regression & 551.921 & 4 & 137.980 & 154.527 & $0.000^{\mathrm{e}}$ \\
\hline & Residual & 2720.730 & 3047 & 0.893 & & \\
\hline & Total & 3272.651 & 3051 & & & \\
\hline
\end{tabular}

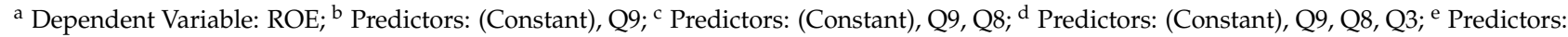
(Constant), Q9, Q8, Q3, Q2; Source: Research data, authors proceeding, SPSS ver. 25.

\section{References}

1. Agwu, M.E.; Onwuegbuzie, H.N. Effects of international marketing environments on entrepreneurship development. J. Innov. Entrep. 2018, 7, 1-14. [CrossRef]

2. Réklaitis, K.; Pileliené, L. Principle Differences between B2B and B2C Marketing Communication Processes. Manag. Organ. Syst. Res. 2019, 81, 73-86. [CrossRef]

3. Godwin, L.R. The ultimate definition of marketing. Mark. Rev. 2019, 19, 43-49. [CrossRef]

4. Kalieva, O.M.; Ivanchenko, O.V.; Mirgorodskaya, O.N. The role of marketing environment and target audiences in the process of territory brand formation. Eur. Res. Stud. 2018, 21, 63. Available online: https://search.proquest.com/docview/2162695317 ?accountid=37662 (accessed on 19 October 2020).

5. Al-Waely, D. The Impact of Careful Application of Growth Management Policies and Sustainable Development on the Changing Marketing Environment. Eur. J. Econ. Stud. 2019, 8, 3-18.

6. Mose, A.; Syaifuddin, M. Analysis of Macro and Micro Environment on the Marketing Strategy Formulation and the Influence to the Competitive Advantage (Case Study). Acad. Strateg. Manag. J. 2016, 15, 35-41. Available online: https://search.proquest. com/docview / 1954424257 ?accountid=37662 (accessed on 19 October 2020).

7. IIA. Definition of Internal Auditing. 2020. Available online: https://na.theiia.org/standards-guidance/mandatory-guidance/ Pages/Definition-of-Internal-Auditing.aspx (accessed on 19 October 2020).

8. COSO. Internal Control-Integrated Framework. 2013. Available online: https://www.coso.org/Documents/990025P-ExecutiveSummary-final-may20.pdf (accessed on 19 October 2020).

9. Furtună, C.; Ciucioi, A. Internal Audit in the Era of Continuous Transformation. Survey of Internal Auditors in Romania. Audit. Financiar. 2019, 17, 452-472. [CrossRef]

10. Lobo, G.; Wang, C.; Yu, X.; Zhao, Y. Material Weakness in Internal Controls and Stock Price Crash Risk. J. Account. Audit. Financ. 2020, 35, 106-138. [CrossRef]

11. Kuang, Y.F.; Lee, G.; Qin, B. Whistleblowing Allegations, Audit Fees, and Internal Control Deficiencies. Contemp. Account. Res. 2021, 38, 32-62. [CrossRef]

12. Kolektiv, A. Česko-Anglický Slovník Pojišt'ovnictví; Grada Publishing: Praha, Czech Republic, 2007.

13. Váchal, M.; Vochozka, M. Podnikové Řizení; Grada Publishing: Praha, Czech Republic, 2013.

14. Kamps, T. Systematic Chasing for Economic Success: An Innovation Management Approach; Anchor: Hamburg, Germany, 2013 ; p. 120.

15. Lenz, R.; Hahn, U. A synthesis of empirical internal audit effectiveness literature pointing to new research opportunities. Manag. Audit. J. 2015, 30, 5-33. [CrossRef]

16. Wachol, J. Modern Management Methods and Process Organization in a Global Enterprise. Sci. Pap. Sil. Univ. Technol. Organ. Manag. 2019, 136, 643-651. [CrossRef]

17. Ferrell, O.C.; Speh, T.W. Marketing Strategy: Text and Cases; Cengage Learning: Boston, MA, USA, 2017.

18. Kor, Y.; Mahoney, J.T. How dynamics, management, and governance of resource deployments influence firm level performance. Strateg. Manag. J. 2005, 26, 489-496. [CrossRef]

19. Zulfikar, R.; Millatina, F.; Mukhtar, M.; Astuti, K.D.; Ismail, T.; Meutia, M.; Fazri, E. Antecedents of Disclosure on Internal Control and Earnings Management. J. Asian Financ. Econ. Bus. 2021, 8, 391-397. 
20. Eniola, A.A. Internal Control Procedures and Firm's Performance. Int. J. Sci. Technol. Res. 2020, 9, 6407-6415.

21. Nazarova, K.; Mysiuk, V.; Gordopolov, V.; Koval, V.; Danilevičienè, I. Preventional audit: Implementation of SOX control to prevent fraud. Bus. Theory Pract. 2020, 21, 293-301. [CrossRef]

22. Bae, G.S.; Choi, S.U.K.; Lamoreaux, P.T.; Lee, J.E. Auditors' Fee Premiums and Low Quality Internal Controls. Contemp. Account. Res. 2021, 38, 586-620. [CrossRef]

23. Sterin, M. The Influence of Audit Committee Expertise on Firms' Internal Controls: Evidence from Mergers and Acquisitions. Account. Horiz. 2020, 34, 193-211. [CrossRef]

24. Tkachenko, V.; Kwilinski, A.; Tkachenko, I.; Puzyrova, P. Theoretical and Methodical Approaches to the Definition of Marketing Risks Management Concept at Industrial Enterprises. Mark. Manag. Innov. 2019, 2, 228-238. [CrossRef]

25. Kupec, V. Risk Audit of Marketing Communication. Eur. Res. Stud. J. 2018, XXI, 125-132. Available online: https://www.ersj.eu/ dmdocuments/2018_XXI_1_11.pdf (accessed on 19 October 2020). [CrossRef]

26. Smidt, L.; Steenkamp, L.; Ahmi, A.; Van der Nest, D.P.; Lubbe, D.S. Assessment of the Purpose of the Use of GAS: A Perspective of Internal Audit Functions in Australia. Int. J. Inf. Syst. Serv. Sect. 2021, 13, 65-82. [CrossRef]

27. Mikušová, M. To be or not to be a business responsible for sustainable development? Survey from small Czech businesses. Econ. Res. Ekon. Istraživanja 2019, 30, 1318-1338. [CrossRef]

28. Dvorský, J.; Petráková, Z.; Polách, J. Assessing the Market, Financial and Economic Risk Sources by Czech and Slovak SMEs. Int. J. Entrep. Knowl. 2019, 7, 30-40. [CrossRef]

29. Chornous, G.; Ursulenko, G. Risk management in banks: New approaches. Ekonomika 2013, 92, 120-132. [CrossRef]

30. Fitriyah, F.K.; Adrianto, Z.; Irawady, C. The Internal Audit Role in Fraud Detection and Prevention. Int. J. Innov. Creat. Chang. 2020, 11, 491-499.

31. Dumitru, M.I.; Burtescu, C. Offences and Penalties in the Internal Audit Activity. Sci. Bull. Econ. Sci. 2015, 14, 36-44. Available online: https: / EconPapers.repec.org/RePEc:pts:journl:y:2015:i:2:p:36-44 (accessed on 19 October 2020).

32. Bożek, S.; Emerling, I. Protecting the Organization Against Risk and the Role of Financial Audit on the Example of the Internal Audit. Oeconomia Copernic. 2016, 7, 485-499. [CrossRef]

33. Kaptein, M. Ethics Management: Auditing and Developing the Ethical Content of Organizations; Kluwer Academic Publishers: Dordrecht, The Netherlands, 1998.

34. Sawyer, L.B. Interní Audit; ČIIA: Praha, Czech Republic, 2000.

35. Guo, F.; Lin, C.; Masli, A.; Wilkins, M.S. Auditor Responses to Shareholder Activism. Contemp. Account. Res. 2021, 38, 63-95. [CrossRef]

36. Putnová, A.; Seknička, P. Etické Řizení ve Firmě; Grada Publishing: Praha, Czech Republic, 2007.

37. Müllerová, L. Auditing pro Manažery aneb Proč a Jak se Ověruje Účetní Závěrka; Wolters Kluwer: Praha, Czech Republic, 2013.

38. Basu, S.K. Auditing: Principles and Techniques; Pearson Education: New Delhi, India, 2007.

39. Kamil, O.A.; Ahmed, E.A. Extent of Adoption of External Auditor on Internal Control in Bank Auditing. Int. J. Innov. Creat. Chang. 2020, 10, 612-624.

40. Macintosh, N.N.; Quattrone, P. Management Accounting and Control Systems; John Wiley \& Sons: Chichester, UK, 2010.

41. Varanini, F.; Ginevri, W. Projects and Complexity; CRC Press: Boca Raton, FL, USA, 2012.

42. Kindisko, E. Organisational Control in University Management; Emerald Publishing: Bingley, UK, 2018.

43. Weickgenannt, A.B.; Hermanson, D.R.; Sharma, V.D. How, U.S. audit committees oversee internal control over financial reporting. Int. J. Audit. 2021, 25, 233-248. [CrossRef]

44. Kitchenko, O.; Kuchina, S. Enterprise Communication Policy Indicators Analysis as a Part of Marketing Audit. Technol. Audit Prod. Reserves 2019, 3, 51-54. [CrossRef]

45. Brown, J.R.; Crosno, J.L. Process and output control in marketing channels: Toward understanding their heterogeneous effects. J. Bus. Ind. Mark. 2019, 34, 735-753. [CrossRef]

46. Frouz, J.; Vindušková, O. Čtení a Psani Odborného Textu v Environmentálních Vědách; Karolinum: Praha, Czech Republic, 2017.

47. Sedláková, R. Výzkum Médii; Grada Publishing: Praha, Czech Republic, 2014.

48. Ferreira, P.; Crema, M.; Verbano, C. Risk management in SMEs: A systematic literature review and future directions. Eur. Manag. J. 2020, 38, 78-94. [CrossRef]

49. Kosacka-Olejnik, M.; Pitakaso, R. Industry 4.0: State of the art and research implications. LogForum 2019, 15, 475-485. [CrossRef]

50. Garbellano, S.; do Rosário Da Veiga, M. Dynamic capabilities in Italian leading SMEs adopting industry 4.0. Meas. Bus. Excell. 2019, 23, 472-483. [CrossRef]

51. Sheth, J.N. Borderless Media: Rethinking International Marketing. J. Int. Mark. 2020, 28, 3-12. [CrossRef]

52. Cluley, R.; Green, W.; Owen, R. The changing role of the marketing researcher in the age of digital technology: Practitioner perspectives on the digitization of marketing research. Int. J. Mark. Res. 2020, 62, 27-42. [CrossRef]

53. Raffaelli, M.; Armstrong, J.; Tran, S.P.; Griffith, A.N.; Walker, K.; Gutierrez, V. Focus on Methodology: Beyond paper and pencil: Conducting computer-assisted data collection with adolescents in group settings. J. Adolesc. 2016, 49, 1-9. [CrossRef] [PubMed]

54. Lukáč, M.; Mihálik, J. Data Envelopment Analysis-a Key to the Museum's 'Secret Chamber' of Marketing? Commun. Today 2018, 9, 106-117. Available online: https:/ / www.communicationtoday.sk/download/22018/08.-LUKAC-MIHALIK-E28093-CT-22018.pdf (accessed on 19 October 2020). 
55. Kramer, R.; Mileva, M.; Ritchie, K.L. Inter-rater Agreement in Trait Judgements from Faces. PLoS ONE 2018, 13 , e0202655. [CrossRef]

56. Wijayatunga, P. A geometric view on Pearson's correlation coefficient and a generalization of it to non-linear dependencies. Ratio Math. 2016, 30, 3-21.

57. Kline, P. The Handbook of Psychological Testing; Routledge: London, UK, 1993.

58. Laval, V. How to Increase the Value-Added of Controlling; Gruyter: Berlin, Germany, 2018.

59. Tsintsadze, A.; Oniani, L.; Ghoghoberidze, T. Determining and Predicting Correlation of Macroeconomic Indicators on Credit Risk Caused by Overdue Credit. Banks Bank Syst. 2018, 13, 114-119. [CrossRef]

60. Písař, P.; Bílková, D. Controlling as a tool for SME management with an emphasis on innovations in the context of Industry 4.0. Q. J. Econ. Econ. Policy 2019, 14, 763-785.

61. Evans, J.D. Straightforward Statistics for the Behavioral Sciences; Thomson Brooks Cole Publishing Co: Boston, MA, USA, 1996.

62. Darlington, R.B.; Hayes, A.F. Regression Analysis and Linear Models: Concepts, Applications, and Implementation; The Guilford Press: New York, NY, USA, 2017.

63. Brabenec, P. Implementační Přiručka: Pokyny k Použití Systému OLINA-Online Nástroje pro Řízení Kvality v Organizacích Zájmového a Neformálního Vzdělávání; Národní institut dětí a mládeže Ministerstva školství, mládeže a tělovýchovy: Praha, Czech Republic, 2012.

64. Hradecká, M. Robotic internal audit-Control methods in the selected company. Agris Line Pap. Econ. Inform. 2019, 11, 31-42. [CrossRef]

65. Batrancea, L.; Nichita, A.; Batrancea, I.; Cesar, A.M.R.V.C.; Forte, D. Sustainable tax behavior on future and current emerging markets: The case of Romania and Brazil. Sustain. Soc. Responsib. Account. Rep. Syst. 2018, 141-158. [CrossRef]

66. Benedic, N.O. The Challenge of Controlling. Int. J. Ind. Eng. Manag. 2015, 6, 153-163. Available online: https://www.researchgate. net/publication/293814491_The_Challenge_of_Controlling (accessed on 19 October 2020).

67. Plant, K.; Barac, K.; Sarens, G. Preparing work-ready graduates-Skills development lessons learnt from internal audit practice. J. Account. Educ. 2019, 48, 33-47. [CrossRef]

68. Jokić, M.; Laban, B.; Arnautovic, I.; Popovic, D.; Popovic, S. The Importance of Preparing an Internal Audit Report in Reporting to Top Management of a Company That Makes Key Management Decisions in Its Work. Ann. Constantin Brancusi Univ. Targu-Jiu. Econ. Ser. 2020, 2, 37-44.

69. Wang, L.; Wang, S.; Dai, Y. The Role of Internal Control in Firm's Sustainable Growth: Evidence from China. J. Account. Financ. 2019, 19, 189-204.

70. Batrancea, L.; Nichita, A.; Batrancea, I.; Gaban, L. The strength of the relationship between shadow economy and corruption: Evidence from a worldwide country-sample. Soc. Indic. Res. 2018, 138, 1119-1143. [CrossRef]

71. Karjalainen, J.; Niskanen, M.; Niskanen, J. The effect of audit partner gender on modified audit opinions. Int. J. Audit. 2018, 22, 449. [CrossRef]

72. Písař, P.; Kupec, V. Innovative Controlling and Audit-Opportunities for SMEs. Probl. Perspect. Manag. 2019, 17, 184-195. [CrossRef]

73. Xhani, N.; Avram, M.; Meçe, I.; Çela, L. Comparative Study on the Organization of Internal Public Audit in Albania and Romania. Audit. Financiar. 2019, 17, 473-485. [CrossRef]

74. Cohen, J.R.; Joe, J.R.; Thibodeau, J.C.; Trompeter, G.M. Audit Partners' Judgments and Challenges in the Audit of Internal Control over Financial Reporting. Auditing 2020, 39, 57-85. [CrossRef]

75. Madleňák, A.; Žulová, J. The Right to Privacy in the Context of the Use of Social Media and Geolocation Services; Wolters Kluwer: Budapest, Hungary, 2019.

76. Petrů, N.; Kramoliš, J.; Stuchlík, P. Marketing tools in the era of digitization and their use in practice by family and other businesses. Econ. Manag. 2020, 23, 199-214.

77. Mayer, K.J.; Salomon, R.M. Capabilities, contractual hazards, and governance: Integrating resource-based and transaction cost perspectives. Acad. Manag. J. 2006, 49, 942-959. [CrossRef]

78. Blštáková, J.; Joniaková, Z.; Jankelová, N.; Stachová, K.; Stacho, Z. Reflection of Digitalization on Business Values: The Results of Examining Values of People Management in a Digital Age. Sustainability 2020, 12, 5202. [CrossRef]

79. Kaban, İ. Central Audit Activities as a Continuous Audit Approach in the Turkish Banking Sector: A Case Study about Frauds in Savings Accounts. J. Marmara Univ. Soc. Sci. Inst. 2020, 15, 254-275. [CrossRef]

80. Bieliaieva, N. International practice of the concepts use of "HR audit", "staff audit", "personnel audit". Econ. Ecol. Socium 2019, 3, 94-101. [CrossRef]

81. Christensen, B.E.; Neuman, S.S.; Rice, S.C. The Loss of Information Associated with Binary Audit Reports: Evidence from Auditors' Internal Control and Going Concern Opinions. Contemp. Account. Res. 2019, 36, 1461-1500. [CrossRef]

82. DeZoort, T.; Doxey, M.; Pollard, T. Root Cause Analysis and Its Effect on Auditors' Judgments and Decisions in an Integrated Audit. Contemp. Account. Res. 2020. [CrossRef]

83. Almaqoushi, W.; Powell, R. Audit committee quality indices, reporting quality, and firm value. J. Bus. Financ. Account. 2021, 48, 185-229. [CrossRef]

84. Pickett, S.K.H. The Internal Auditing Handbook, 3rd ed.; John Wiley \& Sons: Chichester, UK, 2010.

85. Gupta, A. Risk Management and Simulation; CRC Press: London, UK, 2019. 
86. Kupec, V.; Lukáč, M.; Štarchoň, P.; Pajtinková Bartáková, G. Audit of Museum Marketing Communication in the Modern Management Context. Int. J. Financ. Stud. 2020, 8, 39. [CrossRef]

87. Lajili, K.; Lin, L.Y.-H.; Rostamkalaei, A. Corporate governance, human capital resources, and firm performance. J. Gen. Manag. 2020, 45, 192-205. 